See discussions, stats, and author profiles for this publication at: https://www.researchgate.net/publication/273370758

\title{
Study of the Relationship between Procurement Duration and Project Performance in Design-Build Projects: Comparison between Water/Wastewater and Transportation Sectors
}

Article in Journal of Management in Engineering · October 2013

DOI: 10.1061/(ASCE)ME.1943-5479.0000165

CITATIONS

18

3 authors:

Susan M. Bogus

University of New Mexico

74 PUBLICATIONS 521 CITATIONS

SEE PROFILE

Ruoyu Jin

London South Bank University

85 PUBLICATIONS 647 CITATIONS

SEE PROFILE

Some of the authors of this publication are also working on these related projects:

Education View project

Project NM Green: Advancing Sustainable Construction Technology Education View project
READS

199

Giovanni Migliaccio

University of Washington Seattle

133 PUBLICATIONS 858 CITATIONS

SEE PROFILE 


\title{
Study of the Relationship between Procurement Duration and Project Performance in Design-Build Projects: Comparison between Water/Wastewater and Transportation Sectors
}

\author{
Susan M. Bogus, M.ASCE ${ }^{1}$; Giovanni C. Migliaccio²; and Ruoyu Jin ${ }^{3}$
}

\begin{abstract}
Previous studies on building, industrial, and transportation projects found that projects delivered using design-build tend to perform better than projects delivered with the traditional design-bid-build method. However, performance of design-build projects is affected by various factors, with procurement-related factors being among the most influential. Whereas other aspects of procurement have been largely investigated, the effect of procurement duration on project performance has been studied only for design-build transportation projects. In addition, few studies have focused specifically on the delivery of water/wastewater projects. This paper includes the results of a study on the relationship between procurement duration and performance of water/wastewater design-build projects. The study methodology was based on regression analysis of data from a sample of water/wastewater design-build projects. The results show that unlike the transportation sector, procurement duration has little effect on either schedule or cost performance in the water/wastewater sector. Likely reasons for this difference were then explored through a content analysis of procurement documents. DOI: 10.1061/(ASCE)ME.1943-5479.0000165. (C) 2013 American Society of Civil Engineers.
\end{abstract}

CE Database subject headings: Design/Build; Procurement; Project delivery; Water management; Wastewater management.

Author keywords: Design/build; Procurement; Project delivery; Water; Wastewater.

\section{Introduction}

In any type of project delivery method, the procurement of design and construction services can be the key to a successful project delivery. This is especially true for design-build (DB) project procurement, in which the owner is selecting one entity to deliver the project. If the owner is a public entity, such as a water or wastewater utility, the selection process must also be fair and transparent. These expectations mean that procurement of a design-build team often takes considerable time and consumes considerable resources (on both the owner's and design-builder's parts).

When using traditional design-bid-build project delivery, public sector owners procure design and construction services separately. For these projects, the selection process is well-established: design firms are typically selected based on qualifications, and construction firms are selected based on price through the submission of sealed bids. The fundamental challenge of design-build team procurement is the need to balance or combine these two vastly

\footnotetext{
${ }^{1}$ Associate Professor, Dept. of Civil Engineering, Univ. of New Mexico, Albuquerque, NM 87131 (corresponding author). E-mail: sbogus@unm .edu

${ }^{2}$ Assistant Professor, Dept. of Construction Management, Univ. of Washington, Seattle, WA 98105.

${ }^{3}$ Ph.D. Student, Construction Systems Management Program, Ohio State Univ., 590 Woody Hayes Dr., Columbus, OH 43210; formerly, Graduate Research Assistant, Dept. of Civil Engineering, Univ. of New Mexico, Albuquerque, NM 87131. E-mail: jin.188@buckeyemail.osu.edu

Note. This manuscript was submitted on June 8, 2011; approved on January 4, 2013; published online on January 7, 2013. Discussion period open until March 1, 2014; separate discussions must be submitted for individual papers. This paper is part of the Journal of Management in Engineering, Vol. 29, No. 4, October 1, 2013. (C) ASCE, ISSN 0742-597X/ 2013/4-382-391/\$25.00.
}

different procurement methods (i.e., qualifications versus price). The end result is that owners must clearly develop a justifiable procurement process, and design-build teams need to prepare documents that contain both team qualifications and some type of price guarantee (often based on minimal design definition).

For the owner, the development of the design-build request for proposals (RFP) requires a significant effort. The RFP presents the owner's vision for the project and the requirements for the teams proposing on the design-build project. A design-build RFP may contain very little design definition, or it may contain as much as $30 \%$ design. Because the design is not complete at the time of procurement, the RFP must be very clear in presenting the owner's vision, describing the information required by DB teams in their proposals and stating the process for selecting the design-build firm.

For the DB team, significant time and effort is expended in preparing a design-build proposal. Unlike a design-bid-build proposal for design-only services, in which the design firm competes solely on qualifications, a design-build proposal requires the DB firm to perform a significant, but incomplete, level of design. This incomplete information is used by the design-build team to develop a proposed price for the project. To this end, the design-build firm closely assesses potential project risks and areas of uncertainty and plans out the construction process.

The implementation of design-build in water/wastewater projects is limited. Therefore, what factors contribute to the final performance of water/wastewater projects have not been extensively studied. In a previous study, one of the authors analyzed the relationship between contract payment provisions and project performance for water/wastewater projects and found that contracts using cost-plus-fee with guaranteed maximum price (GMP) contract pricing provisions are more likely to have no schedule or cost growth 
as compared to projects with lump-sum provisions (Bogus et al. 2010).

The study tries to continue filling this gap by studying the relationship between procurement duration and project performance for water/wastewater projects and compares the results with those of a similarly designed study on transportation projects (Migliaccio et al. 2010). Given the significant effort expended by design-build firms in preparing DB project proposals, the authors questioned if allowing firms more time to prepare a proposal would result in improved project performance. The rationale is that when designbuild firms have more time to prepare a proposal, they are able to estimate the project schedule and cost more accurately because they can better develop the design and assess risks and uncertainty.

This initial study is expected to raise research interest on designbuild application in water/wastewater projects. In addition, the research results can provide an insight to design-build water/ wastewater project owners on how to achieve better performance in terms of cost and schedule. The authors have performed similar studies for transportation projects and found that the efficiency of the procurement process is considered critical to a successful implementation of DB (Migliaccio et al. 2008). The authors have also studied the relationship between procurement duration and project success for transportation projects and found a positive relationship between time performance and procurement duration (Migliaccio et al. 2010). Because DB is new to water/wastewater projects, efficiency of DB procurement is also expected to be critical to the success of these projects. To study this relationship, the authors compared the actual design-build procurement duration against project performance (measured using the percentages of schedule growth and cost growth). The water/wastewater data were then compared as an entire sector to similar data from the transportation sector to determine if the results varied by project sector. To explain different results among the two sectors, the authors analyzed the content of procurement documents for both transportation and water/wastewater projects.

\section{Background}

There are many factors affecting project performance. Previous research found that project performance is affected by factors such as the characteristics of project participants, of the project, and of the procurement process (Songer and Molenaar 1997; Ling et al. 2004; Lam et al. 2008). A review of numerous papers [Construction Industry Institute (CII) 1994; Pocock et al. 1997; Molenaar et al. 1999; Molenaar and Songer 1998; Chan et al. 2001; Ling 2004; Ling et al. 2004, 2006, 2008; Wardani et al. 2006; Cheng et al. 2007; Lam et al. 2008; and others] found that the most commonly cited factors affecting project performance were as follows:

1. Characteristics of project participants (effort, experience, and organization);
2. Project characteristics (e.g., project size);

3. Procurement (method and contract type);

4. Project management action;

5. Economic, social, and financial condition;

6. Technology and approach; and

7. Planning.

These factors are likely interrelated, thus making it difficult to isolate any one factor. By focusing this study on design-build water/wastewater projects, the authors tried to limit the variability in project and participant characteristics.

For design-build projects, procurement is a major step in the overall project delivery process. There are several models of design-build procurement (Beard et al. 2001), and owners need to decide early in the process on the number of steps in the evaluation (including whether they will develop a short-list), the selection methodology (including how they will select the winning designbuild firm), and the contract pricing format (including how they will pay the design-build firm). Likewise, design-build firms need to decide early whether to propose on a project or not, so that they can assemble the project team and respond to the RFP.

A common procurement process for design-build teams is the two-step model, which includes many activities (Migliaccio et al. 2009) organized around the two phases represented in Fig. 1. The first step in the process is a prequalification stage in which owners issue a request for qualifications (RFQ) and interested design-build teams submit a statement of qualifications (SOQ). After reviewing the SOQs, the owner makes a short list of the most qualified teams. Short-listed teams are then invited to propose on the design-build project. Typical design-build proposals are comprehensive and may include sections on project team organization, previous experience, project approach, design and construction schedule, preliminary design drawings, and project pricing [Design-Build Institute of America (DBIA) 1996]. Because of the comprehensive nature of design-build proposals, there are many risks and uncertainties associated with their development. Most of these risks and uncertainties arise from the fact that design-build teams are developing construction approaches, schedules, and pricing based on incomplete design.

The ultimate success of a design-build project is dependent on many factors, including the procurement process (Ling et al. 2004). Among other factors, Iyer and Jha (2005) found that short bid preparation time adversely affects the cost performances of projects. Similarly, Ling (2004) found that time given to design-build contractors to bid was crucial for obtaining a good workmanship quality in Singaporean DB projects. In spite of its importance, procurement duration is often arbitrarily identified by early implementers, such as water/wastewater utilities.

Success, which can be subjective, may vary from different project participants' points of view. According to CII research in preproject planning (CII 1994), there are considerable disagreements concerning the relative importance of success factors.

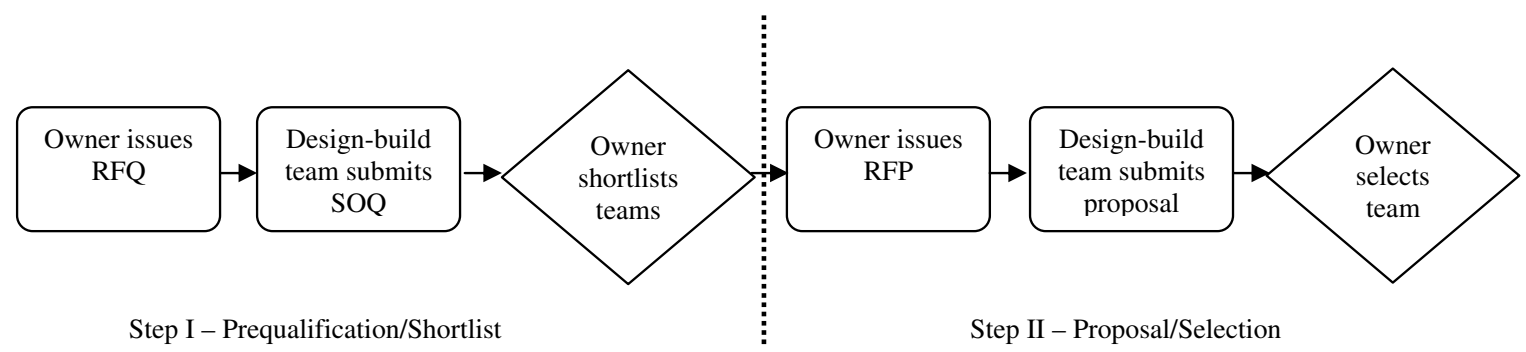

Fig. 1. Two-step procurement process for design-build teams 
Among different groups of project representatives, project managers are most concerned with the execution phase of the project, operation managers are most concerned with the downstream results of the planning and execution phases, and business managers appear to be more concerned with the overall project from a macro level rather than how well it is executed or operated. Among different entities, an owner may care more about budget, completion date, and satisfaction of operation; constructors are concerned more about the profitability; and designers are likely to treat the effectiveness of the technology as the main performance criteria.

Performance criteria can be classified as those based on project outcomes (e.g., timeline, budget, quality), project execution (e.g., safety, change orders, claims and disputes), and those after the execution (e.g., life cycle cost, operation, and maintenance characteristics). The most common criteria of project success are concerned with project control, including budget, schedule control, and quality. Other project success criteria include safety, environmental impact, and number of change orders. Each of these criteria may be decomposed to measurable indexes, either objective or subjective. For example, the cost criteria can be measured in an objective way, in terms of cost growth by comparing the actual cost with the original budget. Schedule, cost, and quality are the most commonly used measures of project success from the studied literature (Konchar and Sanvido 1998; Molenaar et al. 1999; Chan et al. 2002; Hughes et al. 2004; Ling et al. 2008; Hale et al. 2009; Bogus et al. 2010).

\section{Research Methodology}

The primary question answered by this study was whether project performance (specifically cost and schedule performance) is related to procurement duration for design-build projects in different sectors. If a relationship was to be found, guidance could be provided on how to optimally design an efficient procurement process defined as a process that would provide enough time to contractors to assess risks associated with the project venture without dragging the selection process beyond a reasonable time. This study focused on the performance of projects in the water/wastewater sector, although it also provides a comparison to similar data from the transportation sector that were collected by the authors in a previous work (Migliaccio et al. 2010). Data collection was conducted similarly among the two sectors to allow for a valid comparison of the data. Supported by previous studies (Ling 2004; Iyer and Jha 2005), the expectation is that the more time a firm has to prepare a project proposal, the better the ultimate project performance will be. This theory is based on the fact that design-build firms spend a significant amount of time during proposal preparation developing the project design and assessing project risks and uncertainties before developing the estimated cost and schedule. Therefore, the more time that design-build firms have to prepare this information, the better the cost and schedule performance should be.
Data collection consisted of a survey of water/wastewater project owners or their representatives to gather information on completed design-build projects. Owners throughout the United States were contacted to complete an online questionnaire. The questionnaire asked respondents to provide information on the performance of completed design-build projects, including RFP issue date, proposal due date, design start date (assumed to be the same as design-build start date), substantial completion date, contract award price, and final project price. For the schedule-related items, information was collected on both the as-planned dates and the as-built (i.e., actual) dates. Using these data, the following parameters of project procurement duration and project performance in terms of cost and schedule growth were defined:

- Procurement duration (PD) (days): The length of time from RFP issue date to proposal due date (Fig. 2);

- Design-build duration as planned (days): The length of time from as-planned DB start date to as-planned substantial completion date. This only includes the design and construction portion of the project (Fig. 2);

- Design-build duration as built (days): The length of time from as-built DB start date to as-built substantial completion date;

- Total duration as planned (days): The length of time from asplanned RFP issue date to as-planned substantial completion date. This includes the procurement duration along with the design and construction portion of the project (Fig. 2);

- Total duration as built (TDAB) (days): The length of time from as-built RFP issue date to as-built substantial completion date;

- Schedule growth (percentage): The following equations are used to calculate design-build schedule growth (DBSG) and total project schedule growth (TSG):

$B$ Schedule Growth

$$
=\frac{\text { DB Duration As Built }- \text { DB Duration As Planned }}{\text { DB Duration As Planned }} \times 100 \%
$$

TotalProject Schedule Growth

$$
=\frac{\text { TotalDuration As Built }- \text { TotalDuration As Planned }}{\text { TotalDuration As Planned }} \times 100 \% \text {; }
$$

and

- Cost growth (CG) (percentage): The following equation is used to calculate cost growth:

$$
\begin{aligned}
\text { Cost Growth }= & \frac{\text { Project Actual Cost }- \text { Project Contracted Cost }}{\text { Project Contracted Cost }} \\
& \times 100 \%
\end{aligned}
$$

Project contracted cost is the amount determined in the designbuild contract. This cost can be assumed as the owner's planned cost at contract award.

The authors chose schedule and cost growth as the measures of project performance because they are relative performance

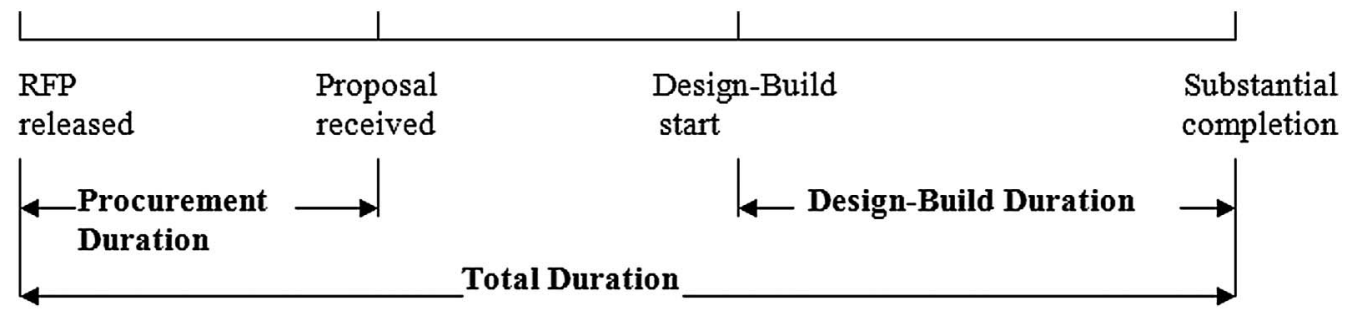

Fig. 2. Illustration of procurement durations used in study 
measures and do not need to be adjusted for project size. Schedule and cost are also two of the most commonly used measures of performance.

To measure the level of effort of the proposers during procurement, the authors developed the procurement duration factor, which is defined as the percent of time spent on preparing the design-build proposal compared to the total project duration. This factor may indirectly account for project size if one assumes that larger projects will have longer total project duration, as was the case for this study. A linear regression analysis of project cost and project duration for the data set showed a strong positive relationship with a correlation coefficient of $0.67, R^{2}$ equal to $44.9 \%$, and $p$-value less than 0.01 The procurement duration factor (PDF) is calculated as follows:

\section{Procurement Duration Factor $=($ Procurement Duration $/$ Total Duration As Built $) \times 100 \%$}

Correlation analysis was used to determine if there was any relationship between procurement duration and project performance. The data were plotted, and the least-squares method of linear regression was used to fit a straight line through the data and calculate the correlation coefficient $(r)$ and $R$-square value.

The data from the water/wastewater sector were compared to similar data from the transportation sector. To explain differences in the relationship types (e.g., negative or positive, strong or weak) between the water/wastewater and transportation sectors, a content analysis of procurement documents of transportation and water/ wastewater projects was performed. This additional research phase was performed to explore the similarities and differences of the RFPs between DB water/wastewater and transportation projects. These peculiarities were used to provide an explanation of the correlation analysis results.

\section{Results}

Data for this study were collected in two steps. An initial set of data was collected under a concurrent study that compared designbuild and design-bid-build project delivery methods for water/ wastewater projects (Bogus et al. 2010). All data were collected through an online survey for projects completed between 2003 and 2009. Data on $31 \mathrm{DB}$ projects were included in the final project sample after removing duplicate or nonresponsive data. Data regarding project RFP issue date, design start date, construction start date, project end date, project contracted cost, and final cost from these $31 \mathrm{DB}$ projects were used for this study. The proposal due date was unavailable in Bogus et al.'s (2010) study, so responders from these 31 projects were contacted again for the proposal due date.

Later, additional data were collected through a new online questionnaire. The questions in this new questionnaire were based on Bogus et al.'s (2010) comparative study. The authors expanded upon the initial data set to obtain data on additional design-build water/wastewater projects. Ultimately, 54 individual contributors provided data on 47 projects. Of the survey respondents, 24 were owners, 11 were owner representatives, 9 were design-builders, and 3 were engineering consultants. The respondents for the entire data collection process were identified through lists of water/wastewater owners collected from the DBIA and the Water Design-Build Council.

Before conducting the overall data sample's linear correlation analysis, the consistency of project performance data between the two data collection efforts was analyzed. This analysis found that two groups of data have similar average values of PD, PDF, and similar standard deviations of PD, PDF, total duration as built (DTAB), DBSG, TSG, and CG. However, the average of DBSG, TSG, project actual cost (PAC), and CG tends to vary. It seems that the duration factors (PD, PDF, and DTAB) are similar between these two groups, whereas the performance data and project cost seem to vary between the two groups. Inferences of means and variances were used to statistically test the consistency of the two groups of data in terms of PD, PDF, DTAB, DBSG, TSG, PAC, and $\mathrm{CG}$. The inferences concerning means and variances prove the hypothesis that the two groups of data have similar mean values of PD, PDF, and DTAB, whereas the mean values of DBSG, TSG, and $\mathrm{CG}$ tended to be different. Because the two data sets were not collected from random samples, there is no expectation that the two samples will necessarily be similar. The nonrandomness of the data collection was because of the small number and difficulty in obtaining data for DB water/wastewater projects.

Given that the data collection procedures were similar and the resulting data were mainly consistent, the resulting data set could be analyzed, and results could be drawn. At the end, the authors collected data on 54 projects, but ultimately, data on 47 projects were used for the analysis because of incomplete data from some of the projects. Of these projects, 20 were from the initial survey (Bogus et al. 2010), and 27 were from the follow-up survey (Jin 2010). The final data are summarized in Table 1.

In handling missing data, the authors first made an evaluation of the type of missing data and concluded that the missing data were completely random. The listwise (casewise) deletion was the method used to handle the missing data in this case. Although the listwise deletion reduced the data sample size, it is a fair reflection of the population because the data were missing completely at random (Howell 2010). The listwise deletion approach is also the most commonly used approach to handle missing data because this approach produces unbiased results. The water/wastewater data were then compared to similar data (see Table 2) from transportation projects to determine if the results varied by project sector. Later, the authors analyzed the content of procurement documents for both transportation and water/wastewater projects to explain different results among the two sectors. Content analysis is a method used to count the presence or frequency of certain words and concepts within texts, and these words and concepts are quantified

Table 1. Summary of Water/Wastewater Project Data

\begin{tabular}{|c|c|c|c|c|c|c|c|}
\hline Metric & $\begin{array}{c}\text { Procurement } \\
\text { duration (days) }\end{array}$ & $\begin{array}{c}\text { Total duration } \\
\text { as built }\end{array}$ & $\begin{array}{l}\text { Procurement } \\
\text { duration factor }\end{array}$ & $\begin{array}{c}\text { Design-build } \\
\text { schedule growth }\end{array}$ & $\begin{array}{l}\text { Total duration } \\
\text { schedule growth }\end{array}$ & $\begin{array}{c}\text { Project actual } \\
\text { cost }(\$ \text { million })\end{array}$ & $\begin{array}{l}\text { Cost } \\
\text { growth }\end{array}$ \\
\hline Number of projects included & 43 & 36 & 40 & 37 & 36 & 42 & 42 \\
\hline Maximum & 457 & 2,406 & $38 \%$ & $94 \%$ & $67 \%$ & 300 & $17 \%$ \\
\hline Minimum & 25 & 144 & $2.9 \%$ & $-53 \%$ & $-43 \%$ & 0.35 & $-13 \%$ \\
\hline Average & 99 & 848 & $13 \%$ & $6.4 \%$ & $3.8 \%$ & 33 & $2.0 \%$ \\
\hline Median & 67 & 745 & $9.4 \%$ & $0.0 \%$ & $0.0 \%$ & 14 & $1.4 \%$ \\
\hline Standard deviation & 86 & 531 & $9.3 \%$ & $27 \%$ & $22 \%$ & 61 & $6.3 \%$ \\
\hline Standard error & 13 & 89 & $1.5 \%$ & $4.4 \%$ & $3.7 \%$ & 9.5 & $1.0 \%$ \\
\hline
\end{tabular}


Table 2. Project Performance Data Comparison between Design-Build Water/Wastewater and Migliaccio et al. (2010)'s Study in Transportation Projects

\begin{tabular}{|c|c|c|c|c|c|c|}
\hline Metric & Maxim & inin & Mec & Medi & $\begin{array}{l}\text { Standa } \\
\text { deviati }\end{array}$ & $\begin{array}{l}\text { ample } \\
\text { umber }\end{array}$ \\
\hline \multicolumn{7}{|c|}{ Procurement duration (days) } \\
\hline water/wastewater & 457 & 25 & 99 & 67 & 86 & 43 \\
\hline Transportation & 139 & 11 & 88 & 91 & 27 & 146 \\
\hline \multicolumn{7}{|c|}{ Project actual cost ( $\$$ million) } \\
\hline water/wastewater & 300 & 0.35 & 33.62 & 13.96 & 61.28 & 42 \\
\hline Transportati & 1,840 & & 53.72 & 6.98 & & 146 \\
\hline \multicolumn{7}{|l|}{ Cost growth } \\
\hline water/waste & $17 \%$ & $\%$ & $2.0 \%$ & $1.4 \%$ & 6.3 & 42 \\
\hline Transportation & $84 \%$ & $-56 \%$ & $0.4 \%$ & $0.6 \%$ & $16 \%$ & 146 \\
\hline \multicolumn{7}{|l|}{ Schedule growth } \\
\hline water/wastewater & $94 \%$ & $-53 \%$ & $6.0 \%$ & $0.0 \%$ & $27 \%$ & 37 \\
\hline Transportation & $118 \%$ & $-58 \%$ & $13 \%$ & $9.2 \%$ & $29 \%$ & 146 \\
\hline
\end{tabular}

and analyzed in terms of their presence, meanings, and relationships (Yu et al. 2006). This method has been used in construction management research to analyze content of various sources, including design-build procurement documents (Yu et al. 2006; Gransberg and Molenaar 2004; Gransberg and Barton 2007; Gransberg and Windel 2008).

\section{Relationship between Schedule Growth and Procurement Duration}

The relationships between DB schedule growth and procurement duration and DB schedule growth and the procurement duration factor are shown in Fig. 3. The regression analysis shows a very weak and negative relationship between schedule growth and either procurement duration or the procurement duration factor. When this relationship is tested using the p-test and a level of significance of 0.05 , the results show that schedule growth has no significant correlation with procurement duration, but a weak correlation with the procurement duration factor. This relationship was also evaluated based on project size to see if the results changed (Table 3). The assumption made is that larger projects (greater than $\$ 50$ million in total project cost) would benefit more from longer procurement duration than smaller projects. The results of the analysis based on project size also showed that there was no significant correlation between schedule growth and either procurement duration or the procurement duration factor. The linear relationship between design-build schedule growth and

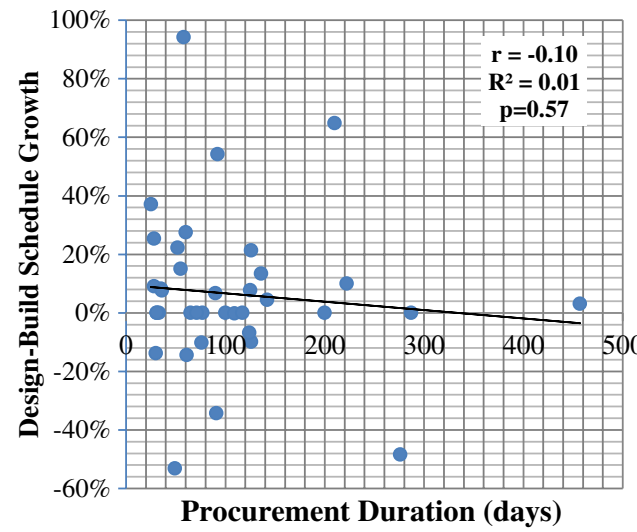

(a) procurement duration was also studied, leading to similar results with that in total schedule growth.

\section{Relationship between Cost Growth and Procurement Duration}

The relationships between cost growth and procurement duration and cost growth and the procurement duration factor are shown in Fig. 4. The regression analysis shows a very weak and positive relationship between cost growth and either procurement duration or the procurement duration factor. When this relationship is tested using the $p$-test and a level of significance of 0.05 , the results show that there is no significant correlation between cost growth and either procurement duration or the procurement duration factor. This relationship was also evaluated based on project size to see if the results changed (Table 3). The results of the analysis based on project size also showed that there was no significant correlation between cost growth and either procurement duration or the procurement duration factor.

\section{Comparison between Water/Wastewater Projects and Transportation Projects}

The regression analysis of procurement duration and project performance in the water/wastewater sector was compared to a similar analysis for the transportation sector (Migliaccio et al. 2010) to determine if the results would be different for different types of sectors. The study of design-build transportation projects showed a strong, negative correlation between schedule growth and procurement duration, such that the longer the design-build firms had to prepare their proposal, the better their schedule performance (Migliaccio et al. 2010). This result is different from the findings for design-build water/wastewater projects, in which there was no significant correlation between schedule growth and procurement duration. The study on design-build transportation projects showed a weak, negative correlation between cost growth and procurement duration, which was considered to be statistically insignificant (Migliaccio et al. 2010). The results found for design-build water/ wastewater projects were also considered to be statistically insignificant for any relationship between cost growth and procurement duration.

\section{Discussion of Findings}

This study found no significant relationship between procurement duration and project performance in design-build water/wastewater

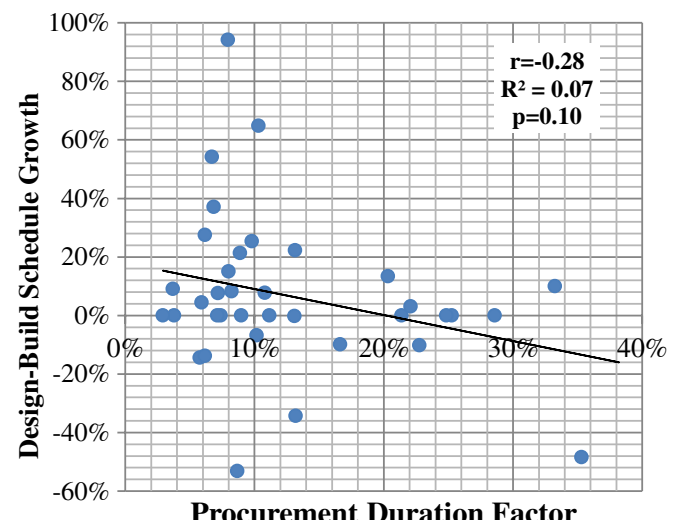

(b)

Fig. 3. Overall project schedule growth in relation to (a) procurement duration; (b) procurement duration factor 
Table 3. Relationships between Project Duration-Related Factors and Project Performance for Different Sizes of Projects

\begin{tabular}{crrrrrrrr}
\hline & $\begin{array}{c}\text { Low-complexity } \\
\text { projects }(N=20)\end{array}$ & & \multicolumn{2}{c}{$\begin{array}{c}\text { Medium-complexity } \\
\text { projects }(N=18)\end{array}$} & & \multicolumn{2}{c}{$\begin{array}{c}\text { High-complexity } \\
\text { projects }(N=8)\end{array}$} \\
\cline { 2 - 3 } Metric & DBSG & CG & & DBSG & CG & & DBSG & CG \\
\hline PD & & & & & & & & \\
$r$ & -0.20 & 0.15 & & -0.02 & 0.42 & & -0.57 & -0.56 \\
$p$ & 0.45 & 0.53 & & 0.94 & 0.11 & & 0.32 & 0.32 \\
PDF & & & & & & & & \\
$r$ & -0.18 & 0.36 & & -0.33 & 0.15 & & -0.47 & -0.54 \\
$p$ & 0.49 & 0.14 & & 0.25 & 0.58 & & 0.42 & 0.35 \\
\hline
\end{tabular}

Note: $r=$ correlation coefficient; DBSG = design-build schedule growth; $\mathrm{CG}=$ cost growth; $\mathrm{PD}=$ procurement duration; $\mathrm{PDF}=$ procurement duration factor; though $N$ shows the total number of projects within each size of project, the sample number used in the correlation analysis is less than the total project sample because of the incomplete data; low-complexity projects: actual cost is less than $\$ 10$ million, medium complexity projects cost from $\$ 10-50$ million, and high complexity projects cost more than $\$ 50$ million.

projects. This means that design-build firms that had more time to prepare their design-build proposal did not necessarily perform any better in terms of schedule and cost growth than firms that had less time to prepare their proposal. The data in Fig. 3 illustrate this fact, and it is also apparent from Fig. 3 that the projects with the highest schedule growth also had short procurement durations. When the size of the project is taken into account (through the use of the procurement duration factor), the worst performing projects (with schedule growth $>20 \%$ ) all had procurement duration factors of $10 \%$ or less. This indicates that providing a longer procurement duration may not result in better schedule performance, but that providing too little time for procurement can result in very poor schedule performance.

When comparing these results with a similar study of designbuild transportation projects (Migliaccio et al. 2010), neither sector (water/wastewater and transportation) showed a relationship between cost growth and procurement duration. However, the transportation sector showed a significant relationship between schedule growth and procurement duration, such that projects with a longer procurement duration resulted in lower schedule growth. This was not the case for water/wastewater projects. When comparing these two sectors in terms of design-build project delivery, it is speculated that there is a significant difference in design complexity between the two sectors. The water/wastewater sector appears to have much

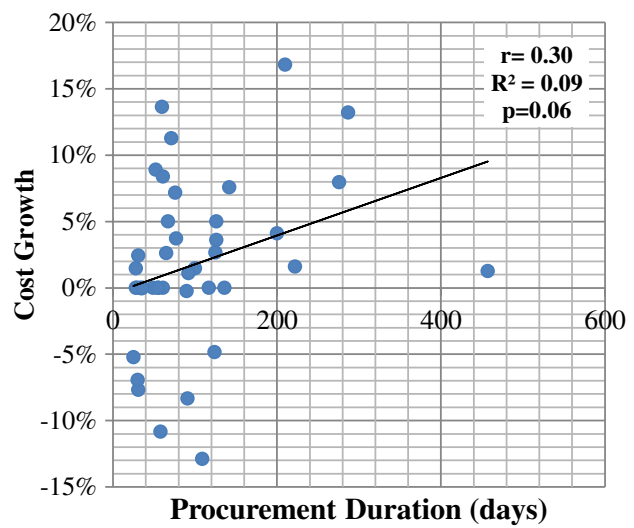

(a) more complexity and uncertainty in early designs, which may mean that ultimate project performance is more influenced by project characteristics than procurement duration. Contributing to this design uncertainty are factors that vary from project to project and from day to day, such as influent water quality and the effectiveness of treatment technologies at different times of the year. For transportation projects, the design criteria and guidelines are clearly spelled out by organizations such as the American Association of State Highway and Transportation Organizations (AASHTO). This reduces the variability of designs and the uncertainty in early design decisions, which means that design-build teams can better plan the project during the procurement phase, and the end result is better schedule performance when given additional time to prepare the design-build proposal. Given the design uncertainty associated with water/wastewater projects, perhaps an even longer procurement duration than what was studied here would result in improved performance. Another reason for the different relationship between the two sectors could be because of the data sample collected. In the transportation sector, all projects in a state are run through a single state transportation agency. The fact that transportation agencies may oversee many projects may have decreased variability in that data set because of consistent owner-specific characteristics, such as procurement process, evaluation criteria to design-builders, and long-term business relationships with the same design-builders. When these factors are the same for design-build transportation projects, the time for design-builders to prepare the proposal became a more significant issue for the final schedule performance (Migliaccio et al. 2010). In contrast, the nature of the water/ wastewater sector means that projects were located throughout the United States and were built by a wide variety of owner organizations. Most water/wastewater owners complete projects infrequently, which limits their procurement experience. This significant difference in owner-specific characteristics, such as owner type (public or private), procurement philosophy, and RFP content could have contributed more to project performance other than procurement duration. The potential reasons of the differences of this linear relationship analysis between these two sectors are further explored through content analysis of procurement documents of transportation and water/wastewater projects.

\section{Content Analysis}

The results of the data analysis show that there were differences between this study of water/wastewater projects and

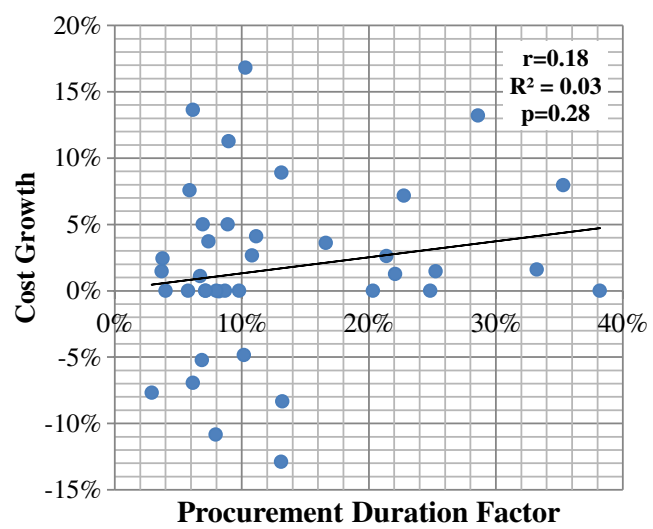

(b)

Fig. 4. Overall project cost growth in relation to (a) procurement duration; (b) procurement duration factor 
Migliaccio et al.'s (2010) study of transportation projects. These differences were especially seen in the relationship between procurement duration and schedule growth. Because of these differences, further analysis was done using content analysis to try to determine why these two types of projects behaved differently.

Content analysis is applied in the study of the relationship between procurement duration and project performance. Based on those differences and similarities of relationships between water/ wastewater and transportation projects, related hypotheses concerning the procurement duration and project performance are provided as follows:

- There are some variables included in the procurement documents that impact the project final cost and schedule performance;

- In most DB transportation projects, schedule issues are of greater concern than in water/wastewater projects;
- The project costs in both transportation and water/wastewater projects may not be so easily controlled by the design-builder, even though sufficient time is provided to prepare the cost proposal; and

- Cost change and schedule change are not necessarily interrelated in both transportation and water/wastewater projects.

The RFP is a significant data source to test the hypotheses. The authors analyzed RFP documentation, searching for information on (1) the RFP content structure; (2) procurement approach (e.g., low bid versus best value); (3) DB team selection criteria; and (4) other variables. These additional variables included those that are assumed to influence the ultimate performance of a DB project. They are listed in Part IV of Table 4. More detailed information on these variables is available in Jin (2010).

The objective of the content analysis was to explore the similarities and differences of the DB RFPs between water/wastewater

Table 4. Content Analysis: Summary of Results

\begin{tabular}{|c|c|c|c|}
\hline Topic & Variable & Transportation $(\%)$ & Water/wastewater $(\%)$ \\
\hline \multirow[t]{7}{*}{ I. RFP content structure } & Executive summary & 33 & 46 \\
\hline & Proposer information and certifications & 21 & 7.7 \\
\hline & Financial proposal & 23 & 33 \\
\hline & Management proposal & 36 & 25 \\
\hline & Technical proposal & 96 & 92 \\
\hline & Price proposal & 96 & 93 \\
\hline & Optional proposal & 17 & 8 \\
\hline \multirow[t]{4}{*}{ II. Procurement approach } & Sole source & 0 & 13 \\
\hline & Qualification-based & 12 & 33 \\
\hline & Best value & 40 & 47 \\
\hline & Low-bid & 48 & 7 \\
\hline \multirow[t]{17}{*}{ III. Selection criteria } & Design-builders' responsiveness & 54 & 50 \\
\hline & Cost & 93 & 88 \\
\hline & Design-builders' understanding of the project and approach & 44 & 77 \\
\hline & Design-build team organization & 78 & 77 \\
\hline & The design-builder's capability, experience & 70 & 92 \\
\hline & Financial capacity & 27 & 42 \\
\hline & Maintenance and operation capacity & 38 & 25 \\
\hline & Design quality program & 67 & 33 \\
\hline & Construction quality program & 76 & 25 \\
\hline & Safety program & 38 & 15 \\
\hline & Schedule/work breakdown plan & 58 & 54 \\
\hline & Subcontracting & 33 & 25 \\
\hline & Warranty & 9.1 & 0.0 \\
\hline & Environmental protection & 18 & 8.3 \\
\hline & Coordination & 57 & 25 \\
\hline & Aesthetics & 29 & 0.0 \\
\hline & Risk management & 0 & 27 \\
\hline \multirow[t]{19}{*}{ IV. Other variables } & Number of procurement steps $(1 / 2 / 3)$ & $19 / 67 / 15$ & $67 / 20 / 13$ \\
\hline & Stipend or honorarium to proposers & 65 & 7 \\
\hline & Mention of percentage of design completion in the proposal & 12 & 25 \\
\hline & Liquidated damages & 35 & 17 \\
\hline & Preproposal conference & 56 & 75 \\
\hline & Interviews or oral presentations by proposers & 44 & 75 \\
\hline & Owner-mandated project price cap & 16 & 0 \\
\hline & Owner-mandated project completion date & 59 & 8 \\
\hline & Incentives for early completion & 8 & 8 \\
\hline & Preproposal site visit & 35 & 62 \\
\hline & Required project life cycle cost analysis & 19 & 25 \\
\hline & Circumstances for proposal exclusion & 31 & 50 \\
\hline & Dispute resolution process & 15 & 23 \\
\hline & Change order process & 12 & 23 \\
\hline & Payment procedures & 44 & 23 \\
\hline & Expected warranties & 41 & 8 \\
\hline & Design-builders provide the subcontractor list & 26 & 33 \\
\hline & Design-builders' duties in personnel training & 26 & 0 \\
\hline & Owner's right to use ideas from unacceptable proposals & 12 & 0 \\
\hline
\end{tabular}


projects and transportation projects to add explanatory power to this study. For projects in which RFP documents were not available, other procurement documents, such as the RFQ or contracts, were evaluated. In total, documents were reviewed for 31 transportation projects and 17 water/wastewater projects.

The frequency rate was the measure used to compare between water/wastewater and transportation projects.

\section{Frequency Rate \\ $=$ Number of Times Terms Present/Number of Projects}

For example, if the term stipend or honorarium appeared 13 times in 31 transportation projects, the frequency rate for this term was $13 / 31$, or $42 \%$.

\section{Content Analysis-Summary of Results}

The key differences between the two sectors in terms of frequency rate are presented in Table 4.

In terms of RFP structure, both sectors required many similar items in the DB proposals, such as a separate price proposal and technical proposal. Within the major sections identified in Table 4, some of the key areas of difference are

- Within the management proposal, transportation projects more frequently cited the need for subcontractor management, communication, and cost and schedule control;

- Within the technical proposal, transportation projects more frequently cited geotechnical/earthwork plans, construction plans, and maintenance plans; and

- Within the price proposal, transportation projects more frequently cited lump sum pricing.

In terms of procurement approach, the most common selection methods for transportation projects were low bid and best value. For water/wastewater projects, the most common selection methods were qualifications-based and best value.

In terms of selection criteria, the design-builders' understanding of the project and approach, the design-builders' financial capacity, and their experience are more frequently used in water/wastewater than in transportation projects. In contrast, design and construction quality programs, safety programs, and coordination and communication of the designer/engineer, contractor, and owner are much more commonly evaluated in transportation projects. Aesthetics are sometimes evaluated in transportation projects, whereas they are not considered in water/wastewater projects. Finally, the designbuilders' risk management program is sometimes evaluated in water/wastewater projects, but not in transportation projects.

Several other variables were also evaluated. The terms with key differences between sectors are listed subsequently.

- Transportation projects had a higher frequency for liquidated damages in the contract.

- Two-step is the main process used in transportation project procurement, whereas one-step is widely used in water/wastewater projects.

- Most transportation projects provide stipends to responsive but unsuccessful proposers, whereas most water/wastewater projects do not have any stipend or honorarium for proposers.

- More than half of transportation project owners have a deadline for the project's substantial completion, whereas only a few water/wastewater project owners have the requirement of the project completion date.

- The site visit before proposal submission is much more frequently required or encouraged in water/wastewater than transportation projects.
- More water/wastewater project RFPs contain the circumstances under which proposals may be rejected.

- More transportation project RFPs contain the payment procedure and the requirements of the design-builders' warranty.

- More than half of transportation project RFPs contain clauses of the proposers' right to protest regarding the procurement, whereas only a few water/wastewater project owners have similar clauses.

\section{Discussion of Content Analysis Results}

The content analysis is used to explore the reasons for the differences in the linear relationships between procurement duration and project performance for transportation and water/wastewater projects.

\section{Schedule and Cost Growth in Transportation and Water/Wastewater Projects}

Most transportation and water/wastewater projects require designbuilders to prepare separated technical and cost proposals. Most owners even have two different committees to evaluate the two proposals. The DB teams' schedule and cost performance are not necessarily related. For example, a design-builder who finishes a project before the planned completion date is not necessarily also under budget. It may be because of the employment of more workers or the use of more advanced management techniques that the design-builder manages an earlier completion, but meanwhile, the cost increases.

\section{Procurement Duration and Schedule Growth in Transportation and Water/Wastewater Projects}

The duration from RFP issue to due date is the time given for design-builders to prepare proposals on the RFPs. There is a preassumption that the design-builder is the main party that can influence and control the project timeline. Provided that the designbuilder has good previous performance and an excellent schedule control team, the dominating factor is the time provided for the design-builders to prepare proposals. Migliaccio et al.'s (2010) study in transportation projects has supported the hypothesis. However, this conclusion could not be made in water/wastewater projects. The reason may be that there are other influencing factors that impact the project schedule that could not be controlled by designbuilders' time and effort spent during the proposal preparation. These factors can be found from the content analysis:

- More transportation project proposals have a subcontractor management plan (SMP). Because subcontractors are the direct executors of construction, the design-builder's management and communication with subcontractors are important to control the project timeline. The requirement of SMP in transportation projects helps design-builders control the project schedule.

- More transportation project proposals have a schedule plan and geotechnical and earthwork plans. The preparation of these plans at earlier stages like the RFP phase may be beneficial for the design-builder to control the schedule.

- Owner's relative weighted evaluation criteria of design-builders may also impact design-builders' schedule performance. Review of the RFP documents indicate that transportation project owners weigh more on cost criteria, and water/wastewater owners weigh more on proposers' qualifications.

- Owners' procurement process may impact the performance of the design-builder. Most owners in transportation projects use a two-step selection process, whereas many water/wastewater project owners use one-step. The two-step may enable the owner to have a better qualified design-builder because there is a prequalification process and a further evaluation of proposers. 
- The stipend paid for unsuccessful proposers may motivate potential design-builders to participate in the project contract competition. As a result, the owner may select a DB team among a larger pool of proposers. Given that transportation projects adopted stipends at a significantly higher frequency, this increased competition may explain why transportation projects have a stronger relationship between project duration and schedule growth.

- Owner's requirements on project completion date, liquidated damages for late completion, and an incentive policy for early completion probably impact the schedule control.

In addition to the aforementioned factors of project schedule growth, there might be other factors not contained in the procurement documents of transportation and water/wastewater projects:

- One factor might be the whole procurement duration (from owners' preplanning to contract award). The duration used in this study is a part of the whole procurement duration. It is the time for design-builders to prepare DB proposals. The owners' effort during the procurement may also influence the project schedule growth.

- The design-builder's team effort and experience in scheduling.

- Owner and design-builder organization: according to some practitioners, the procurement duration is more a function of the organization and/or the scope of the project, and would not be an indicator of project duration change (A. J. Lundt, personal communication, 2009).

\section{Procurement Duration and Cost Growth in Transportation and Water/Wastewater Projects}

There are weak linear relationships between procurement duration and cost growth in both transportation and water/wastewater projects. It may also be explained by the fact that there are a series of other factors that influence cost change. Only after excluding these factors can the cost growth be controlled basically by the designbuilders' efforts and time to prepare proposals. These factors might include:

- Percentage of design completion in the proposal: The more design completed in the proposal and before the construction starts, the more reliable cost estimates can be;

- Owner's budget for the project: Owners' maximum amount for the project can influence the design-builders' preparation of cost proposals because the design-builder will have to pay more attention to controlling the estimated cost;

- Life cycle cost or value engineering: The cost proposal can vary if design-builders are required to prepare price proposals in consideration of the life cycle costs;

- Maintenance, operation, and warranty: The cost proposal may also vary if design-builders are responsible for the maintenance and operation and required to provide a warranty;

- Design-builders' cost estimate and control team may have a large impact on the cost performance. The team's effort, experience, and capacity can impact both schedule and cost; and

- Other factors may account for DB project cost growth, such as the whole PD and owner's sophistication.

\section{Conclusions}

The goal of this study was to determine if there was any relationship between procurement duration and project performance for designbuild water/wastewater projects. The data indicate that procurement duration does not influence project performance, measured in terms of schedule and cost growth. These results were then compared to a similar study of design-build transportation projects. Neither sector (water/wastewater and transportation) showed a relationship between cost growth and procurement duration, which indicates that procurement duration is not a limiting factor when determining project costs in design-build proposals. For transportation projects, there was a relationship between schedule growth and procurement duration, whereby a longer procurement duration resulted in projects with lower schedule growth. One reason for this difference may be related to the greater complexity and uncertainty associated with the design of water/wastewater projects compared to transportation projects. Another reason is that most of the transportation projects in the study came from the same state DOT. Previous studies have suggested that owner organization has a large impact on project performance. These differences were further studied through content analysis of procurement documents.

The content analysis of proposal requirements indicated several differences between the transportation sector and the water/ wastewater sector that could account for why procurement duration and schedule growth are related in transportation but not in water/ wastewater projects. More transportation project proposals have a SMP that helps design-builders control the project schedule. More transportation project proposals require preparation of schedule plans at the proposal stage, which can benefit the overall project schedule by identifying potential issues up front. Review of the RFP documents indicate that transportation project owners are more likely to use a two-step selection process, whereas many water/wastewater project owners use one-step. The two-step process may enable the owner to have a better qualified design-builder because there is a prequalification process and a further evaluation of proposers. Among other issues identified through the content analysis, transportation projects adopted stipends at a significantly higher frequency, which may increase competition and explain why transportation projects have a stronger relationship between project duration and schedule growth. The owner's requirements on project completion date, liquidated damages for late completion, and an incentive policy for early completion probably also impact the schedule control. All of these factors should be considered during procurement as a way to ultimately improve project performance.

\section{References}

Beard, L. J., Loulakis, C. M., and Wundram, C. E. (2001). Design-build: Planning through development, McGraw-Hill, New York, 2-180.

Bogus, S. M., Shane, J. S., and Molenaar, K. R. (2010). "Contract payment provisions and project performance: An analysis of municipal water and wastewater facilities." Public Works Manage. Policy, 15(1), 20-31.

Chan, P. C. A., Ho, C. K. D., and Tam, M. C. (2001). "Effect of interorganizational teamwork on project outcome." J. Manage. Eng., 17(1), 34-40.

Chan, P. C. A., Scott, D., and Lam, W. M. E. (2002). "Framework of success criteria for design/build projects." J. Manage. Eng., 18(3), $120-128$

Cheng, W. L. E., Li, H., and Fox, P. (2007). "Job performance dimensions for improving final project outcomes.” J. Constr. Eng. Manage., 133(8), $592-599$.

Construction Industry Institute (CII). (1994). "Pre-project planning: Beginning a project the right way." CII Pre-Project Planning Research Team, Univ. of Texas at Austin, Austin, TX, 1-25.

Design-Build Institute of America (DBIA). (1996). "The proposal process - Responding to RFQs and RFPs." Design-Build Manual of Practice, Document Number 301, Design-Build Institute of America, Washington, DC.

Gransberg, D. D., and Barton, F. R. (2007). "Analysis of federal designbuild request for proposal evaluation criteria." J. Manage. Eng., 23(2), $105-111$.

Gransberg, D. D., and Molenaar, K. (2004). "Analysis of owner's design and construction quality management approaches in design/build projects." J. Manage. Eng., 20(4), 162-169. 
Gransberg, D. D., and Windel, E. (2008). "Communicating design quality requirements for public sector design/build projects." J. Manage. Eng., 24(2), 105-110.

Hale, R. D., Shrestha, P. P., Gibson, E. G., and Migliaccio, C. G. (2009). "Empirical comparison of design/build and design/bid/build project delivery methods." J. Constr. Eng. Manage., 135(7), 579-587.

Howell, D. C. (2010). Statistical methods for psychology, Cengage Learning, Belmont, CA.

Hughes, S. W., Tippett, D. D., and Thomas, K. W. (2004). "Measuring project success in the construction industry." Eng. Manage. J., 16(3), 31-37.

Iyer, K. C., and Jha, K. N. (2005). "Factors affecting cost performance: Evidence from Indian construction projects." Int. J. Project Manage., 23(4), 283-295.

Jin, R. (2010). "Relationship between procurement duration and project performance in design-build water/wastewater projects." Master's thesis, Univ. of New Mexico, Albuquerque, NM.

Konchar, M., and Sanvido, V. (1998). "Comparison of U.S project delivery systems.” J. Constr. Eng. Manage., 124(6), 435-444.

Lam, W. M. E., Chan, P. C. A., and Chan, W. M. D. (2008). "Determinants of successful design-build projects." J. Constr. Eng. Manage., 134(5), 333-341.

Ling, Y. Y. F. (2004). "Key determinants of performance of design-bidbuild projects in Singapore." Build. Res. Inf., 32(2), 128-139.

Ling, Y. Y. F., Chan, L. S., Chong, E., and Ee, P. L. (2004). "Predicting performance of design-build and design-bid-build projects." J. Constr. Eng. Manage., 130(1), 75-83.

Ling, Y. Y. F., Ibbs, W. C., and Hoo, Y. W. (2006). "Determinants of international architectural, engineering, and construction firms' project success in China." J. Constr. Eng. Manage., 132(2), 206-214.
Ling, Y. Y. F., Low, P. S., Wang, Q. S., and Egbelakin, T. (2008). "Models for predicting project performance in China using project management practices adopted by foreign AEC firms." J. Constr. Eng. Manage., 134(12), 983-990.

Migliaccio, G. C., Bogus, S. M., and Chen, A. (2010). "Effect of duration of design-build procurement on performance of transportation projects." Transportation Research Record 2151, Transportation Research Board, Washington, DC, 67-73.

Migliaccio, G. C., Gibson, G. E., and O'Connor, J. T. (2008). "Changing project delivery strategy: An implementation framework." Sage J. Public Works Manage. Policy, 12(3), 483-502.

Migliaccio, G. C., Gibson, G. E., and O'Connor, J. T. (2009). "Procurement of design-build services: Two-phase selection for highway projects." J. Manage. Eng., 25(1), 29-39.

Molenaar, R. K., and Songer, D. A. (1998). "Model for public sector design-build project selection." J. Constr. Eng. Manage., 124(6), 467-479.

Molenaar, R. K., Songer, D. A., and Barash, M. (1999). "Public-sector design/build evolution and performance." J. Manage. Eng., 15(2), 54-62.

Pocock, B. J., Liu, Y. L., and Tang, H. W. (1997). "Prediction of project performance based on degree of interaction." J. Manage. Eng., 13(2), $63-76$.

Songer, D. A., and Molenaar, R. K. (1997). "Project characteristics for successful public-sector design-build.” J. Constr. Eng. Manage., 123(1), $34-40$.

Wardani, A. E. M., Messner, I. J., and Horman, J. M. (2006). "Comparing procurement methods for design-build projects." J. Constr. Eng. Manage., 132(3), 230-238.

Yu, A. T. W., Shen, Q., Kelly, J., and Hunter, K. (2006). "Investigation of critical success factors in project briefing by way of content analysis." J. Constr. Eng. Manage., 132(11), 1178-1186. 